\title{
Politics and the Histories of International Law: An Introduction to the Special Issue
}

\author{
Anne Peters \\ Director, Max Planck Institute for Comparative Public Law and International \\ Law, Heidelberg, Germany \\ anne.peters@mpil.de
}

Raphael Schäfer

Research Fellow, Max Planck Institute for Comparative Public Law and International Law, Heidelberg, Germany schaefer@mpil.de

\author{
Randall Lesaffer \\ Professor of Legal History, University of Leuven, Belgium \\ Professor of Legal History, Tilburg University, The Netherlands \\ randall.lesaffer@kuleuven.be
}

'L'histoire n'est pas une religion. L'historien n'accepte aucun dogme, ne respecte aucun interdit, ne connaît pas de tabous.

Il peut être dérangeant.'1

\footnotetext{
1 'Liberté pour l'histoire' (L'appel du 12 décembre 2005), available at: http://www.lph-asso.fr/ index34d.html?option=com_content\&view=article\&id=2\&Itemid=13\&lang=fr (last accessed on 6 July 2020$)$.
} 
Almost all scholarship on the history of international law has political implications and repercussions. The putatively 'ideological nature' of international legal scholarship with 'political preferences remaining concealed,', the 'concern that legal scholarship could turn out to be nothing more than the pseudo-objective defence of ruling ideologies' 3 is acute not only when scholars examine contemporary international legal problems but also when they examine the history of international law. ${ }^{4}$

Famously, Hans Kelsen has denounced a 'tendency wide-spread among writers on international law' to produce 'political ideology'. ${ }^{5}$ Kelsen sought to escape this by writing books of a 'purely juristic character.' 6 In his foreword to the commentary on the UN Charter of 1950, he stressed that this work dealt 'with the law of the Organisation, not with its actual or desired role in the international play of powers. Separation of law from politics in the presentation of national or international problems is possible. ${ }^{7}$

In contrast to what Kelsen believed and what he aspired to do, it is nowadays doubted that purging international legal scholarship of politics would work. Martti Koskenniemi at the opening conference of the European Society of International Law in Florence in 2004 put this as follows: 'The choice is not between law and politics but between one politics of law, and another. Everything is at stake, but not for everyone. ${ }^{8}$

Historians of international law also have to make political choices. The question is not whether but why and in which ways international legal scholarship and, consequently, historical accounts of international law are 'political'.

To begin with, the object under investigation is itself a political matter. International law's content is to a large extent shaped by the political power

2 Feichtner, Isabel. 'Realizing Utopia through the Practice of International Law'. European Journal of International Law 23(4) (2012), 1143-1157, 1154.

3 Bernstorff, Jochen von. 'International Legal Scholarship as a Cooling Medium in International Law and Politics'. European Journal of International Law 25(4) (2014), 977-99o, 977-978.

4 See on politics and ideology as a challenge for international legal scholarship Peters, Anne. 'International Legal Scholarship under Challenge', in International Law as a Profession, eds. Jean d'Aspremont, Tarcisio Gazzini, André Nollkaemper and Wouter Werner (Cambridge: Cambridge University Press, 2017), 117-159, 122-134.

5 Kelsen, Hans. 'Preface to the First Edition' (New York: Rinehart, 1952), in Principles of International Law, eds. Hans Kelsen and Robert Warren Tucker (New York: Holt, 2nd ed. 1967), ix.

6 Ibid.

7 Kelsen, Hans. The Law of the United Nations (London: Stevens, 1950), viii (emphasis added).

8 Koskenniemi, Martti. 'International Law in Europe: Between Tradition and Renewal'. European Journal of International Law 16(1) (2005), 113-124, 123. 
of the parties which negotiated the treaties and who framed them according to their political values. And of course the historical personalities, the scholars of the past, were likewise embedded in a political context. Their work we study now was driven by their personal beliefs, institutional allegiances and instrumental considerations which are difficult to disentangle. A case in point is Hugo Grotius' Mare Liberum, whose argument for an open sea was in line with the interests of the Dutch East India Company, a quasi-sovereign actor. ${ }^{9}$ Or, the Dominican Friar Francisco de Vitoria issued a formal opinion ('parecer') on 'the education and conversion of the Indians to the holy faith' upon request by Emperor Charles v, King of Spain. That legal opinion today enjoys different, even contrary interpretations. While some read it as a defense of the conquista, others read it as a subtle critique of the enterprise. ${ }^{10}$

And this current reading again depends on the current political context by which the historian is inevitably influenced. As Richard Bourke reminds us, 'historical research usually engages the past under the influence of contemporary concerns', and consequently, 'relations between historical analysis and moral judgment' are 'often blurred.' ${ }^{11}$

Research on the history of international law is not only inherently political, but also specifically 'risk-prone.'12 Writing on topics such as genocide, the state of exception, failed states, humanitarian intervention, asymmetrical war, or cyber-attacks is especially liable to being used and abused by participants in political controversies. In fact, when it comes to writing history, the fight over master narratives is usually fierce among competing political factions or governments. ${ }^{13}$ This is notorious in territorial disputes. The 'historical evidence'

The Dutch East India Company had solicited De jure praedae in 1604 which remained unpublished. Mare liberum was a reworked version of its chapter 12 which Grotius published anonymously in 1609 in the context of the negotiations for the Twelve Years Truce with Spain, at the instigation of Oldenbarnevelt, the political leader of the Holland regents. Cf. Van Ittersum, Martine Julia. 'Hugo Grotius: The Making of a Founding Father of International Law', in The Oxford Handbook of the Theory of International Law, eds. Anne Orford and Florian Hoffmann (Oxford: Oxford University Press, 2016), 82-10o.

10 See only Zapatero, Pablo. 'Legal Imagination in Vitoria. The Power of Ideas'. Journal of the History of International Law 11(2) (2009), 221-271, 248; Allemann, Daniel S. 'Empire and the Right to Preach the Gospel in the School of Salamanca'. The Historical Journal 62(1) (2019), 35-55, 36 .

11 Bourke, Richard. 'European Empire and International Law from the Eighteenth Century to the Twentieth Century'. The Historical Journal, published online by Cambridge University Press on 16 June 2020, 1-10, 1 .

12 Even if this is risk-prone in a different sense than the natural sciences' and life sciences' development of the atomic bomb, genetic engineering, bio-enhancement, and the like.

13 The elite's attempt to control history typically starts in the schoolbooks. See for the USA, e.g., Goldstein, Dana. 'Two States. Eight Textbooks. Two American Stories'. New York 
presented in boundary disputes before the International Court of Justice has been famously dubbed as 'Foreign Office International Legal History'.14 The governments normally seek to harness academia, to instrumentalise scholarship for their ends, and to 'seal' debates by decreeing an 'official' history. ${ }^{15}$

The infamous example are memory laws which consecrate specific views on atrocities of the past (especially genocidal massacres) and which sometimes additionally criminalise the denial of those atrocities. ${ }^{16}$ Some of these attempts to close historical debates by law have been criticised by historians, most famously in the petition 'Liberté pour l'histoire' by French historians reacting against various French memory laws. ${ }^{17}$

Battles over the 'correct' history are not only common among those who wield political positions but constantly go on in academic camps, even if inextricably bound up with the desire to generate knowledge. Maybe a blurry line between the two social systems (academia and politics) can be drawn along the primary purpose of the activity of the participants belonging to the respective systems, and the methods they employ.

Scholarly (and scientific) activity is normally understood to be a 'serious and systematic attempt to find out the truth', as the German Constitutional

Times (12 January 2020), available at: https://www.nytimes.com/interactive/2020/o1/12/ us/texas-vs-california-history-textbooks.html (last accessed on 6 July 2020).

14 Bederman, David J. 'Foreign Office International Legal History', in Time, History and International Law, eds. Matthew Craven, Malgosia Fitzmaurice and Maria Vogiatzi (Leiden: Martinus Nijhoff, 2007), 43-63. Current examples are the invocation of 'historical titles' in the South China Sea dispute (Permanent Court of Arbitration, The South China Sea Arbitration (The Republic of Philippines v. The People's Republic of China), Case No. 2013-19 (Award on Jurisdiction and Admissibility of 29 October 2015; Merits of 12 July 2016). Another example is the quarrel over the name of the Former Yugoslav Republic Macedonia which was settled in the Prespas-Agreement of 12 June 2018 as 'Republic North Macedonia'.

15 A current example is furnished by the Russian and Ukrainian governing elites who are fighting over political history of the region. See the 'Open Letter from Scholars and Experts on Ukraine Re. the So-Called "Anti-Communist Law"', published in Krytika, April 2015, available at: https://krytyka.com/en/articles/open-letter-scholars-and-experts-ukraine -re-so-called-anti-communist-law (last accessed on 6 July 2020): 'Over the past 15 years, Vladimir Putin's Russia has invested enormous resources in the politicization of history. It would be ruinous if Ukraine went down the same road, however partially or tentatively. Any legal or "administrative" distortion of history is an assault on the most basic purpose of scholarly inquiry: pursuit of truth. Any official attack on historical memory is unjust. Difficult and contentious issues must remain matters of debate.'

16 See the comparative study by Hennebel, Ludovic and Thomas Hochmann, eds. Genocide Denials and the Law (Oxford: Oxford University Press, 2011).

17 See above (n. 1). 
Court once put it. ${ }^{18}$ This scholarly 'truth' is relative to the standpoint of the researcher and his or her research question, it is provisional, and subject to refutation. ${ }^{19}$ This relativity notwithstanding, it is not the main objective of scholarship to make politics but to understand and explain, with help of steps (in the case of legal scholarship: with arguments) which are comprehensible and which can be replicated (at least intellectually) by others. Along this line, many scholars of history seek to uncover various aspects of past events and debates and to contextualise them, seeking to reach a modicum of objectivity and neutrality. ${ }^{20}$ Of course, more context does not by itself lead to more objectivity. An over-contexualisation might do quite the opposite, as it suggests or even creates a 'context' which for the historical actors was of no importance. ${ }^{21}$

And as far as evaluation is concerned, the scholarly strategies reach from conscious attempts to avoid judgment (as far as possible), while others are more prone to judging deliberately and to employing historical insights in contemporary political debates. ${ }^{22}$ For example, Patrick Boucheron, in his inaugural lecture of 2015 at the Collège de France called for 'une réassurance scientifique du régime de vérité de la discipline historique que nous devons collectivement travailler'. In order to establish this 'regime of truth of the discipline of historiography' we need to reconcile 'l'érudition et l'imagination'. And the key objective of 'érudition' is, according to Boucheron, to 'faire front à

18 BVerfGE 35, 79 (1 BvR 424/71 and 1 BvR 325/72), para. 128 (29 May 1973 ('alles, was nach Inhalt und Form als ernsthafter planmäßiger Versuch zur Ermittlung der Wahrheit anzusehen ist'; our translation).

19 Seminally on the 'situatedness' of the researcher: Haraway, Donna. 'Situated Knowledges: The Science Question in Feminism and the Privilege of Partial Perspective'. Feminist Studies 14(3) (1988), 575-599.

20 See, e.g., Lesaffer, Randall. 'International Law and Its History: The Story of an Unrequited Love', in Time, History and International Law, eds. Matthew Craven, Malgosia Fitzmaurice and Maria Vogiatzi (Leiden: Martinus Nijhoff, 2007), 27-41.

21 Zapf, Holger. Methoden der Politischen Theorie: Eine Einführung (Leverkusen-Opladen: Verlag Barbara Budrich, 2013), 77. See also Gaukroger, Stephen. 'Undercontextualization and Overcontextualization in the History of Science'. Isis. A Journal of the History of Science Society 107(2) (2016), 340-342.

22 No one today claims that scholarship can be 'value-free'. See Weber, Max. "Objectivity" in Social Sciences', in The Methodology of the Social Sciences, eds. Edward Albert Shils and Henry A. Finch (New York: Free Press, 1949), 49-112; Maus, Heinz and Friedrich Fürstenberg, eds. Der Positivismusstreit in der deutschen Soziologie (Berlin and Neuwied: Luchterhand, 1969). See the very useful exegesis of Max Weber by Dreier, Horst. 'Max Webers Postulat der Wertfreiheit in der Wissenschaft und die Politik', in Wissenschaft und Politik, eds. Horst Dreier and Dietmar Willoweit (Stuttgart: Franz Steiner, 2010), 35-70. 
l'entreprise pernicieuse de tout pouvoir injuste.'23 With Boucheron, we might say that erudition is inextricably bound up with our sense of justice. Each and every scholar therefore walks somewhere in between the unattainable ideal of 'scholarly neutrality' on the one side, and partisan politics on the other side. ${ }^{24}$ And it is a matter of personal inclination whether he or she errs more to the one or the other.

It is against this background that an international conference was held at the Max Planck Institute for Comparative Public Law and International Law in Heidelberg under the auspices of the Journal of the History of International Law on 16th and 17th February 2019. Unfortunately, one of the journal's editors, Emmanuelle Tourme Jouannet, could not join us. Scholars of different origin, background and training discussed the duties and responsibilities of those researching on the history of international law. Under the heading 'Politics and the Histories of International Law', this special issue brings together a broad collection of eleven articles, which find their origins in presentations given at the conference. Illustrating some key historical manifestations of politics the contributions not only reflect the 'plurality of visions of the history of international law' but also debate 'the methods, subjects and uses, as well as the bounds and dead-ends' of the discipline. ${ }^{25}$

We wish to thank all colleagues who helped us in organising the conference, notably Anette Kreutzfeld, Richard Dören, and Robert Stendel. The conference was funded by the Deutsche Forschungsgemeinschaft (DFG, German Research Foundation) - Project Number PE 631/6-1 and supported by Koninklijke Brill NV. We gratefully acknowledge these contributions.

\section{Bibliography}

Allemann, Daniel S. 'Empire and the Right to Preach the Gospel in the School of Salamanca'. The Historical Journal 62(1) (2019), 35-55.

23 Boucheron, Patrick. 'Ce que Peut l'Histoire'. Collège de France, Leçon inaugurale prononcée le jeudi 17 décembre 2015, para. 67, available at: http://books.openedition.org/ cdf/4507 (last accessed on 6 July 2020).

24 Engi, Lorenz. 'Wissenschaft und Werturteil - Wissenschaft und Politik'. Ancilla iuris 4 (2009), 25-33.

25 Tourme Jouannet, Emmanuelle and Anne Peters. 'The Journal of the History of International Law: A Forum for New Research'. Journal of the History of International Law 16(1) (2014), 1-8, 7-8. 
Bederman, David J. 'Foreign Office International Legal History', in Time, History and International Law, eds. Matthew Craven, Malgosia Fitzmaurice and Maria Vogiatzi (Leiden: Martinus Nijhoff, 2007), 43-63.

Bernstorff, Jochen von. 'International Legal Scholarship as a Cooling Medium in International Law and Politics'. European Journal of International Law 25(4) (2014) 977-99o.

Boucheron, Patrick. 'Ce que Peut l'Histoire'. Collège de France, Leçon inaugurale prononcée le jeudi 17 décembre 2015, para. 67, available at: http://books.openedition .org/cdf/4507 (last accessed on 6 July 2020).

Bourke, Richard. 'European Empire and International Law from the Eighteenth Century to the Twentieth Century'. The Historical Journal, published online by Cambridge University Press on 16 June 2020, 1-10.

Dreier, Horst. 'Max Webers Postulat der Wertfreiheit in der Wissenschaft und die Politik', in Wissenschaft und Politik, eds. Horst Dreier and Dietmar Willoweit (Stuttgart: Franz Steiner, 2010), 35-70.

Engi, Lorenz. 'Wissenschaft und Werturteil - Wissenschaft und Politik'. Ancilla iuris 4 (2009), 25-33.

Feichtner, Isabel. 'Realizing Utopia through the Practice of International Law'. European Journal of International Law 23(4) (2012), 1143-1157.

Gaukroger, Stephen. 'Undercontextualization and Overcontextualization in the History of Science'. Isis. A Journal of the History of Science Society 107(2) (2016), 340-342.

Goldstein, Dana. 'Two States. Eight Textbooks. Two American Stories'. New York Times (12 January 2020).

Haraway, Donna. 'Situated Knowledges: The Science Question in Feminism and the Privilege of Partial Perspective'. Feminist Studies 14(3) (1988), 575-599.

Hennebel, Ludovic and Thomas Hochmann, eds. Genocide Denials and the Law (Oxford: Oxford University Press, 2011).

Van Ittersum, Martine Julia. 'Hugo Grotius: The Making of a Founding Father of International Law', in The Oxford Handbook of the Theory of International Law, eds. Anne Orford and Florian Hoffmann (Oxford: Oxford University Press, 2016), 82-10o.

Kelsen, Hans. 'Preface to the First Edition' (New York: Rinehart, 1952), in Principles of International Law, eds. Hans Kelsen and Robert Warren Tucker (New York: Holt, 2nd ed., 1967).

Kelsen, Hans. The Law of the United Nations (London: Stevens, 1950).

Koskenniemi, Martti. 'International Law in Europe: Between Tradition and Renewal'. European Journal of International Law 16(1) (2005), 113-124.

Lesaffer, Randall. 'International Law and Its History: The Story of an Unrequited Love', in Time, History and International Law, eds. Matthew Craven, Malgosia Fitzmaurice and Maria Vogiatzi (Leiden: Martinus Nijhoff, 2007), 27-41. 
Maus, Heinz and Friedrich Fürstenberg, eds. Der Positivismusstreit in der deutschen Soziologie (Berlin and Neuwied: Luchterhand, 1969).

Peters, Anne. 'International Legal Scholarship under Challenge', in International Law as a Profession, eds. Jean d'Aspremont, Tarcisio Gazzini, André Nollkaemper and Wouter Werner (Cambridge: Cambridge University Press, 2017), 117-159.

Tourme Jouannet, Emmanuelle and Anne Peters. 'The Journal of the History of International Law: A Forum for New Research'. Journal of the History of International Law 16(1) (2014), 1-8.

Weber, Max. 'Objectivity” in Social Sciences', in The Methodology of the Social Sciences, eds. Edward Albert Shils and Henry A. Finch (New York: Free Press, 1949), 49-112.

Zapatero, Pablo. 'Legal Imagination in Vitoria. The Power of Ideas'. Journal of the History of International Law 11(2) (2009), 221-271.

Zapf, Holger. Methoden der Politischen Theorie: Eine Einführung (Leverkusen-Opladen: Verlag Barbara Budrich, 2013). 